\title{
UREA CLEARANCE IN THE IMMEDIATE POST-NATAL PERIOD
}

\author{
BY \\ JOHN THOMSON, M.D., D.P.H., D.C.H. \\ (From the Department of Child Life and Health, University of Edinburgh)
}

In the growing volume of literature concerning renal function in the newborn infant there is as yet little mention of urea clearance in the immediate post-natal period: that is in the first three or four days of life. Barnett (1940) made observations on inulin clearance in infants of five to nine days old. The investigations of McCance and Young (1941) were made on infants of seven to fourteen days old. They also made observations on three infants aged six to thirteen days: these infants had meningocoeles. Experimental studies were made by Barnett, Perley, and McGinnis (1942) on a twenty-four hour old infant who had an extroversion of the urinary bladder. The conditions of the experiment were abnormal. The work of Gordon, Harrison, and McNamara (1942) deals with full-term infants of eight to sixty-five days and premature infants of seven to seventy-three days old. Dean and McCance (1947) have carried out some most interesting experimental studies on infants of two, three, and four days old. In these instances, the infants suffered from inoperable meningomyelocoeles. They were studied under conditions which do not normally pertain at this age period.

The observations now recorded were made on healthy spontaneously delivered full-term male and female infants. In each case the mother had a normal pregnancy and puerperium. No clinical abnormality was detected in these infants during their stay in hospital. The infants are divided into three groups each of which, with the method used and the data obtained, are described seriatim. The groups are referred to as groups I, II, and III.

\section{Method}

Group I. This group comprised nine male infants. The details of age and weight at the time of the commencement of the observation period are given in table 1. The surface area, calculated according to the recommendations of Howland and Dana (1913), and the factor required for correction to an adult standard of $1.73 \mathrm{sq}$. $\mathrm{m}$. are given in the same table. The duration of the observation period is given in each case. Five of the infants were observed for two periods, making a total of fourteen observation periods, during which forty-one specimens of urine were collected.

These specimens of urine were obtained by using an apparatus previously described (Thomson, 1944). The apparatus gives accurate timing and avoids the need for continual observation. In order to present a non-wettable surface to the urine, a coating of hard paraffin is used as far as possible. Even so, a small quantity of urine is lost in wetting surfaces. Experimental observation has shown this quantity to be approximately $0.3 \mathrm{ml}$. This amount has, therefore, been added to the measured volume of each specimen of urine and the resulting volume is considered to be the true volume of urine passed. It is the figure used for all calculations.

The apparatus was fixed in position about 9 a.m. and, after the first passage of urine had been timed and recorded, specimens of urine were collected. They were preserved under toluol and were analysed in the biochemistry laboratory of the Royal Infirmary, Edinburgh, as soon afterwards as possible. The method of Van Slyke was used for the estimation of urea.

The specimens of blood were obtained by heel stab and were taken during the observation period. The time at which they were taken is given in table 1. In one instance, owing to the long duration of the observation period, two specimens were taken. These specimens were analysed in the biochemistry laboratory of the Royal Hospital for Sick Children, Edinburgh. Nessler's rejagent was used to determine the ammonia liberated by urease and the results read by electro-photometer.

Results. The mean volume of the individual specimens of urine was $12.25 \mathrm{ml}$. and the standard deviation $8.12 \mathrm{ml}$. The mean minute volume was $0.0682 \mathrm{ml}$. and the standard deviation $0.0650 \mathrm{ml}$. The standard deviations are expressive of the great range of the total and the minute volumes. These figures are in conformity with those published showing the average daily volume of the urine, and the average volume of urine passed at each voiding, in the first five days of life (Thomson, 1944).

The mean blood urea nitrogen was $19 \mathrm{mg}$. per $100 \mathrm{ml}$., with a standard deviation of $7.00 \mathrm{mg}$. This compares favourably with the published work of Lucas et al. (1921), Schultz and Pettibone (1915), and Sedgwick and Ziegler (1920).

The urea clearances which have been calculated 
DATA OF GROUP I INFANTS

\begin{tabular}{|c|c|c|c|c|c|c|c|c|}
\hline $\begin{array}{c}\text { Case } \\
\text { no. }\end{array}$ & $\begin{array}{c}\text { Age at } \\
\text { commence- } \\
\text { ment of } \\
\text { observa- } \\
\text { tions } \\
\text { (hours) }\end{array}$ & $\begin{array}{l}\text { Weight } \\
\text { (g.) }\end{array}$ & $\begin{array}{l}\text { Surface } \\
\text { area } \\
\text { (sq. m.) }\end{array}$ & $\begin{array}{c}\text { Correction } \\
\text { factor } \\
(1 \cdot 73 / \text { sur- } \\
\text { face area } \\
\text { in sq. } m .)\end{array}$ & $\begin{array}{l}\text { Total } \\
\text { duration of } \\
\text { observa- } \\
\text { tion period } \\
\text { (hours) }\end{array}$ & $\begin{array}{l}\text { Time at which } \\
\text { blood was taken } \\
\text { after commence- } \\
\text { ment of } \\
\text { observations } \\
\text { (hours) }\end{array}$ & $\begin{array}{l}\text { Number of } \\
\text { urine } \\
\text { specimens }\end{array}$ & $\begin{array}{c}\text { Blood urea } \\
\text { nitrogen } \\
\text { (mg per } \\
100 \mathrm{ml} .)\end{array}$ \\
\hline $\begin{array}{l}1 \mathrm{a} \\
1 \mathrm{~b} \\
2\end{array}$ & $\begin{array}{r}15 \cdot 6 \\
41 \cdot 8 \\
104 \cdot 7\end{array}$ & $\begin{array}{l}3,345 \\
3,289 \\
3,289\end{array}$ & $\begin{array}{l}0 \cdot 2346 \\
0 \cdot 2318 \\
0 \cdot 2318\end{array}$ & $\begin{array}{l}7 \cdot 37 \\
7 \cdot 46 \\
7 \cdot 46\end{array}$ & $\begin{array}{r}22 \cdot 25 \\
8 \cdot 58 \\
52 \cdot 11\end{array}$ & $\begin{array}{r}7 \cdot 66 \\
6 \cdot 25 \\
10 \cdot 83 \\
47 \cdot 00\end{array}$ & $\begin{array}{l}4 \\
2 \\
4\end{array}$ & $\begin{array}{l}23 \\
23 \\
27 \\
19\end{array}$ \\
\hline $\begin{array}{l}3 \\
4 a \\
4 b \\
5 a \\
5 b \\
6 a \\
6 b \\
7 \\
8 \\
9 a \\
9 b\end{array}$ & $\begin{array}{r}34 \cdot 2 \\
23 \cdot 0 \\
51 \cdot 0 \\
53 \cdot 4 \\
123 \cdot 5 \\
31 \cdot 1 \\
102 \cdot 3 \\
45 \cdot 1 \\
50 \cdot 1 \\
19 \cdot 3 \\
29 \cdot 1\end{array}$ & $\begin{array}{l}3,515 \\
3,232 \\
3,090 \\
2,523 \\
2,523 \\
2,892 \\
2,807 \\
3,969 \\
3,232 \\
3,402 \\
3,260\end{array}$ & $\begin{array}{l}0 \cdot 2428 \\
0 \cdot 2296 \\
0 \cdot 2222 \\
0 \cdot 1949 \\
0 \cdot 1949 \\
0 \cdot 2127 \\
0 \cdot 2084 \\
0 \cdot 2647 \\
0 \cdot 2296 \\
0 \cdot 2373 \\
0 \cdot 2305\end{array}$ & $\begin{array}{l}7 \cdot 10 \\
7 \cdot 53 \\
7 \cdot 80 \\
8 \cdot 88 \\
8 \cdot 88 \\
8 \cdot 13 \\
8 \cdot 30 \\
6 \cdot 54 \\
7 \cdot 53 \\
7 \cdot 29 \\
7 \cdot 50\end{array}$ & $\begin{array}{r}16 \cdot 16 \\
8 \cdot 16 \\
6 \cdot 10 \\
4 \cdot 20 \\
8 \cdot 00 \\
3 \cdot 42 \\
6 \cdot 00 \\
11 \cdot 05 \\
10 \cdot 83 \\
9 \cdot 83 \\
21 \cdot 33\end{array}$ & $\begin{array}{r}10 \cdot 25 \\
5 \cdot 08 \\
2 \cdot 00 \\
1 \cdot 83 \\
1 \cdot 50 \\
3 \cdot 50 \\
2 \cdot 58 \\
9 \cdot 58 \\
4 \cdot 58 \\
5 \cdot 33 \\
17 \cdot 00\end{array}$ & $\begin{array}{l}2 \\
3 \\
3 \\
3 \\
4 \\
1 \\
3 \\
2 \\
3 \\
3 \\
4\end{array}$ & $\begin{array}{l}15 \\
16 \\
16 \\
14 \\
14 \\
16 \\
15 \\
16 \\
23 \\
25 \\
24\end{array}$ \\
\hline Totals & & & & & $188 \cdot 02$ & & 41 & \\
\hline Mean & $51 \cdot 75$ & & & & $13 \cdot 43$ & $7 \cdot 58$ & & 19 \\
\hline
\end{tabular}

are shown in fig. 1 where they are plotted against the minute volumes of the urine. Clearances calculated from data obtained during the same observation period have been joined by straight

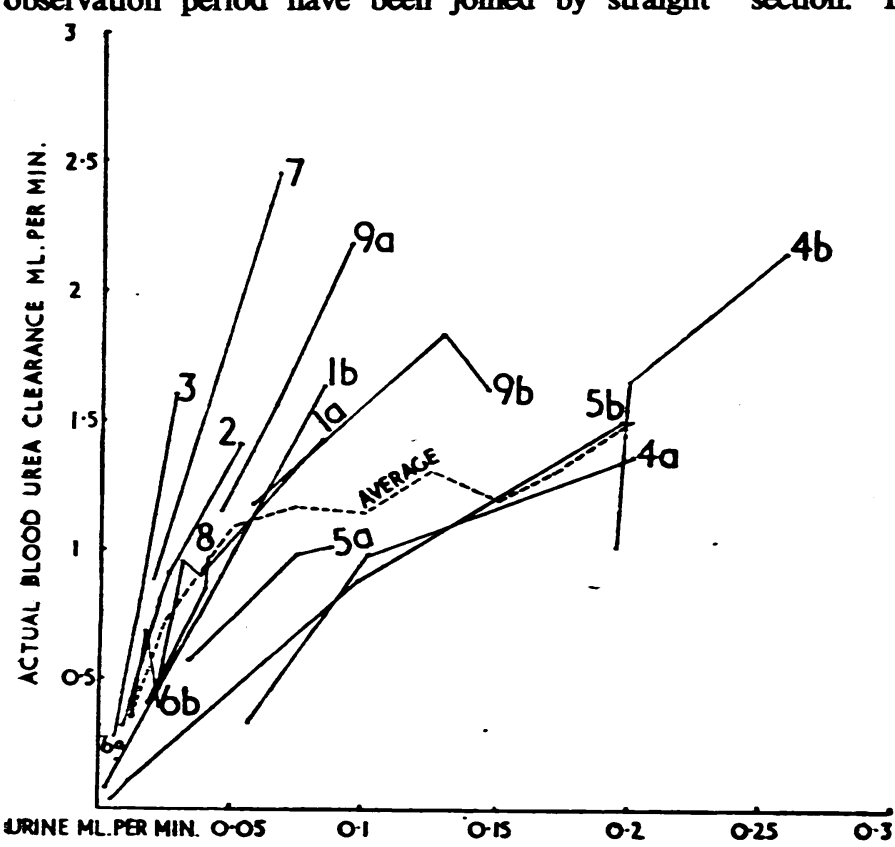

FIG. 1.-Group 1: individual urea clearances. lines. Averages can be struck by raising perpendiculars at selected urine minute volumes to cut these lines. Readings are taken at the point of intersection. The general trend of the figure shows that the volume of blood cleared tends to increase with an increase in the minute volume of the urine. There are three exceptions. The mean volume of blood cleared of urea is $1.0009 \mathrm{ml}$. per minute equal to $0.19 \mathrm{mg}$. urea nitrogen.

Grom II. This group comprised thirteen male infants. In table 2 the same details are given as in the case of the infants in group $I$. In addition the factor for correction for an adult standard of $70 \mathrm{~kg}$. body weight is given. Eight of the infants were observed for two periods making a total of twentyone observation periods during which sixty specimens of urine were obtained. At the commencement of fifteen of the observation periods the infant was given by gavage $3 \mathrm{~g}$. of urea dissolved in 30 ml. of water prior to the fastening on of the apparatus for collecting urine. The infant was not upset by this procedure. When regurgitation did occur, it was infrequent and the amount was small. The remaining six observation periods were in the case of infants who had already been observed and had been given urea approximately twenty-two 
TABLE 2

DATA OF GROUP II INFANTS

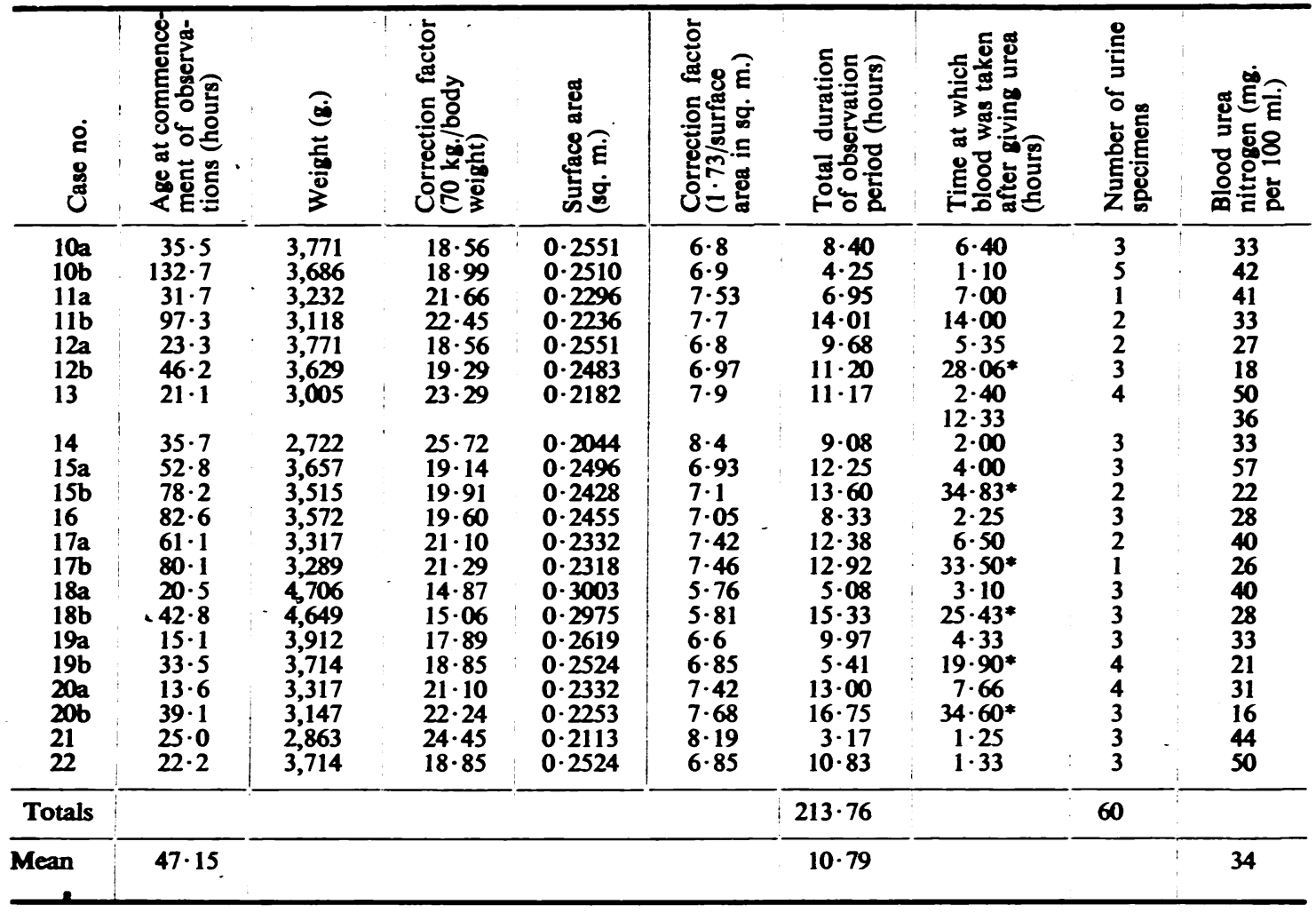

- Urea not given at commencement of second observation period.

hours previously (see table 2). No other change in method was made. Apart from the blood urea nitrogen the differences between the means of the various data in tables 1 and 2 are not statistically significant.

Results. The mean volume of the individual specimens of urine was $14.8 \mathrm{ml}$. and the mean minute volume was $0.0892 \mathrm{ml}$. These figures are not significantly different from the corresponding figures of group I. The mean blood urea nitrogen was $34 \mathrm{mg}$. per $100 \mathrm{ml}$. with a standard deviation of $10.63 \mathrm{mg}$. This is 1.8 times the corresponding figure for group I. The difference between the two figures may be taken as an expression of the amount of urea absorbed following gavage. The urea clearances which have been calculated are shown in fig. 2 where they are plotted against the urine minute volumes. As in fig. 1 clearances calculated from data obtained during the same observation period have been joined by straight lines, and averages obtained by the same method as in group I. The mean volume of blood cleared of urea is $2.008 \mathrm{ml}$. per minute, equal to $0.68 \mathrm{mg}$. urea nitrogen.
Group III. In this group there are sixteen female infants, one of whom was observed on two occasions, making a total of seventeen observation periods. In table 3 details concerning the infants are given as in the case of groups I and II.

The infants were allowed to breast feed at 6 a.m. and given no further food or water until the end of the observation period. At 9 a.m. the urinary bladder was emptied by catheter and the infant immediately given $3 \mathrm{~g}$. urea in $30 \mathrm{ml}$. water by gavage. The infants were not restrained. Thinking it unlikely that urine would be passed spontaneously within an hour, the urine collecting apparatus was not used. Unfortunately this resulted in the loss of one or two specimens. The infants were catheterized at 10 a.m., 11 a.m., and 12 noon and the urinary bladder emptied. Catheterization was not always successful for sometimes urine leaked past the side of the catheter. The volumes of the thirty-four complete individual specimens which were obtained are given in table 3 .

To make sure that the blood urea concentration was raised within an hour, specimens of blood were taken by heel stab from nine of the infants at 9 a.m. 
before giving the urea. At $10 \mathrm{a} . \mathrm{m}$. blood was taken from all the infants: at 11 a.m. blood was taken

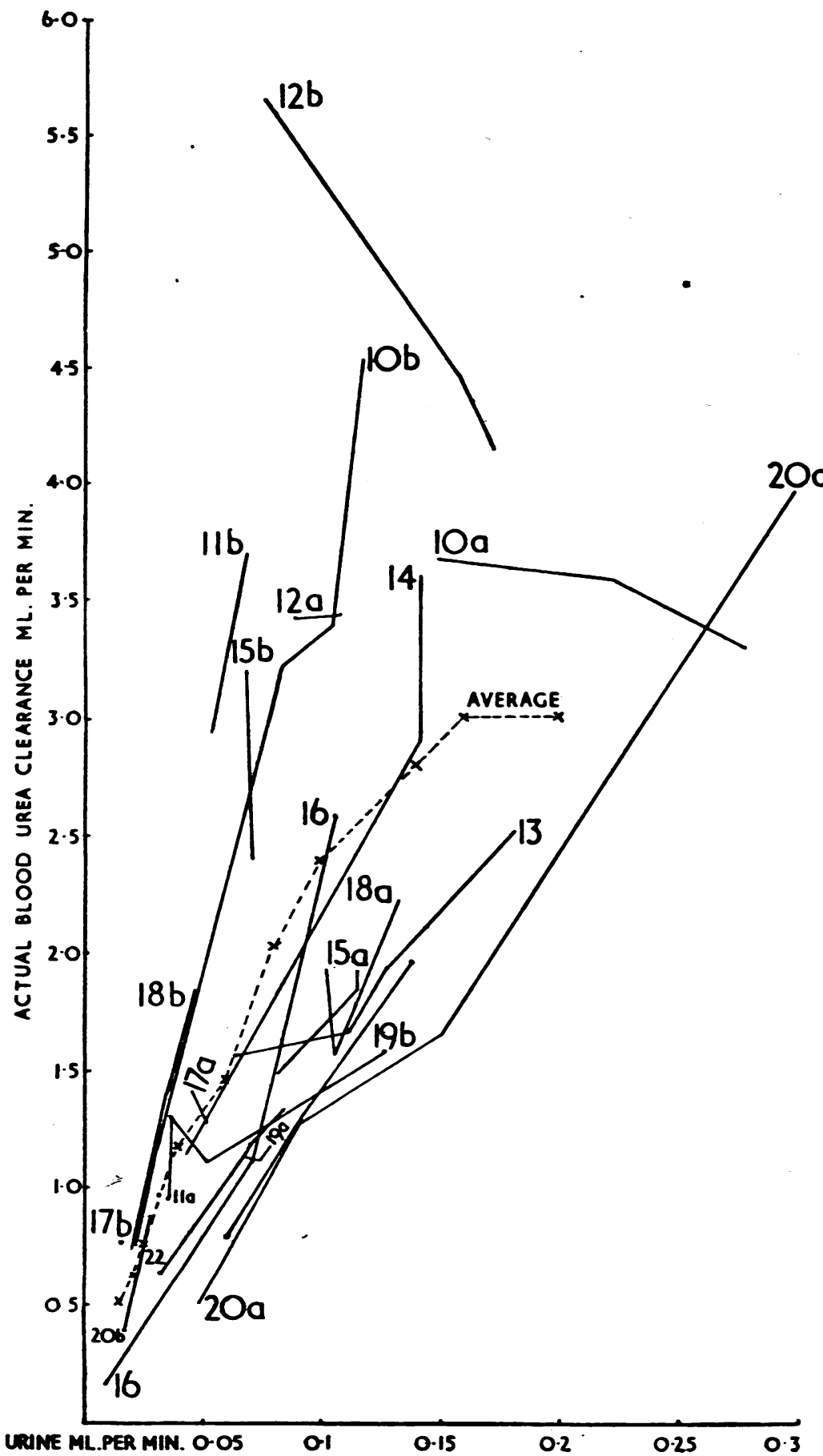

Fig. 2.-Group II: individual urea clearances. from four infants. The blood urea concentration of all these specimens is given in table 3 .

Results. The average of the individual urine minute volumes was $0.0705 \mathrm{ml}$. The difference of this figure from the corresponding figure of $0.0682 \mathrm{ml}$. for group I and $0.0892 \mathrm{ml}$. for group II is not statistically significant.

The mean blood urea nitrogen at 10 a.m. was $43 \mathrm{mg}$. per $100 \mathrm{ml}$.

The urea clearances which have been calculated are shown in fig. 3 where they are plotted against the urine minute volumes. As in figs. 1 and 2 clearances calculated from data obtained during the same observation period have been joined by straight lines, and from these averages have been estimated. The mean volume of blood cleared of urea is $1.5514 \mathrm{ml}$. per minute, equal to 0.6665 mg. urea nitrogen.

Fig. 4 shows the urea concentration of the individual urine specimens plotted against the time at which they were taken. Specimens from the same infant are joined by straight lines. It is shown that with one exception, a day-old infant, there is always an increase in the concentration of urea. In the one exception it will be noted that the urine urea concentration at 9 a.m. was at a higher level than that found in any of the other infants in the group.

\section{Discussion}

The results now recorded may be looked upon as complementary to those of McCance and Young (1941). It is important to note that their observations were made on infants who were in their second week of life, for at this age the fluid intake of the infant who is solely breast fed is more than five times the intake of an entirely breast fed two-day-old infant and about three times that of a three-day-old infant (Thomson, 1944).

The infants of group I of this series of observations 
TABLE 3

DATA OF GROUP III INFANTS

\begin{tabular}{|c|c|c|c|c|c|c|c|c|c|c|c|c|c|}
\hline \multirow{2}{*}{$\begin{array}{l}\dot{g} \\
8 \\
8\end{array}$} & \multirow{2}{*}{ 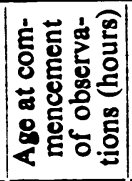 } & \multirow{2}{*}{ 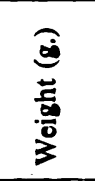 } & \multirow{2}{*}{ 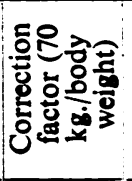 } & \multirow{2}{*}{ 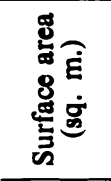 } & \multirow{2}{*}{ 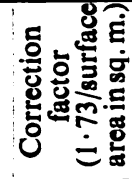 } & \multicolumn{3}{|c|}{$\begin{array}{l}\text { Blood urea nitrogen } \\
\text { per } 100 \mathrm{ml} .\end{array}$} & \multicolumn{4}{|c|}{$\begin{array}{l}\text { Number and volume of urine } \\
\text { specimens }\end{array}$} & \multirow[b]{2}{*}{1 p.m. } \\
\hline & & & & & & 9 a.m. & 10 a.m. & 11 a.m. & $\begin{array}{l}9 \text { a.m. } \\
(\mathrm{ml} .)\end{array}$ & $\begin{array}{l}10 \text { a.m. } \\
\text { (ml.) }\end{array}$ & $\begin{array}{l}11 \text { a.m. } \\
\text { (ml.) }\end{array}$ & $\begin{array}{l}12 \text { noon } \\
\text { (ml.) }\end{array}$ & \\
\hline $\begin{array}{l}23 \\
24 \\
25 \\
26 a \\
2653 \\
? ! \\
28 \\
29 \\
30 \\
31 \\
32 \\
33 \\
34 \\
35 \\
36 \\
37 \\
38\end{array}$ & $\begin{array}{r}75 \cdot 3 \\
118 \cdot 2 \\
38 \cdot 8 \\
131 \cdot 5 \\
203 \cdot 5 \\
146 \cdot 1 \\
44 \cdot 4 \\
53 \cdot 2 \\
63 \cdot 3 \\
106 \cdot 0 \\
132 \cdot 9 \\
127 \cdot 5 \\
121 \cdot 1 \\
153 \cdot 1 \\
39 \cdot 3 \\
126 \cdot 7 \\
212 \cdot 8\end{array}$ & $\begin{array}{l}3,345 \\
2,835 \\
2,948 \\
3,005 \\
3,090 \\
4,167 \\
3,374 \\
2,948 \\
3,515 \\
2,722 \\
3,090 \\
2,438 \\
3,090 \\
2,693 \\
3,685 \\
2,551 \\
2,608\end{array}$ & $\begin{array}{l}20 \cdot 92 \\
24 \cdot 69 \\
23 \cdot 74 \\
23 \cdot 29 \\
22 \cdot 65 \\
16 \cdot 82 \\
20 \cdot 75 \\
23 \cdot 74 \\
19 \cdot 91 \\
25 \cdot 72 \\
22 \cdot 65 \\
28 \cdot 71 \\
22 \cdot 65 \\
25 \cdot 99 \\
18 \cdot 99 \\
27 \cdot 43 \\
26 \cdot 84\end{array}$ & $\begin{array}{l}0.2346 \\
0.2099 \\
0.2154 \\
0.2181 \\
0.2222 \\
0.2743 \\
0 \cdot 2359 \\
0 \cdot 2154 \\
0 \cdot 2428 \\
0 \cdot 2044 \\
0 \cdot 2222 \\
0 \cdot 1908 \\
0 \cdot 2222 \\
0 \cdot 2031 \\
0 \cdot 2510 \\
0 \cdot 1962 \\
0.1990\end{array}$ & $\begin{array}{l}7 \cdot 37 \\
8 \cdot 20 \\
8 \cdot 00 \\
7 \cdot 90 \\
7 \cdot 80 \\
6 \cdot 30 \\
7 \cdot 33 \\
8 \cdot 00 \\
7 \cdot 10 \\
8 \cdot 50 \\
7 \cdot 80 \\
9 \cdot 10 \\
7 \cdot 80 \\
8 \cdot 50 \\
6 \cdot 90 \\
8 \cdot 80 \\
8 \cdot 70\end{array}$ & $\begin{array}{l}24 \\
21 \\
= \\
\overline{-} \\
14 \\
28 \\
21 \\
22 \\
9 \\
- \\
\overline{12} \\
22 \\
-\end{array}$ & $\begin{array}{l}47 \\
57 \\
38 \\
33 \\
33 \\
48 \\
47 \\
44 \\
48 \\
36 \\
52 \\
34 \\
33 \\
43 \\
68 \\
38 \\
35\end{array}$ & $\begin{array}{l}= \\
\bar{Z} \\
\overline{-} \\
\overline{45} \\
\overline{-} \\
\bar{Z} \\
= \\
= \\
\bar{Z} \\
\overline{40} \\
36\end{array}$ & $\begin{array}{l}+ \\
+ \\
+ \\
\text { Nil } \\
+ \\
+ \\
+ \\
+ \\
+ \\
+ \\
+ \\
+ \\
+ \\
\text { Nil } \\
+ \\
+ \\
+\end{array}$ & $\begin{array}{c}6.8 \\
5.6 \\
\text { part } \\
5.9 \\
5.0 \\
6.4 \\
1.9 \\
1.6 \\
5 \cdot 3 \\
\text { part } \\
5.3 \\
\text { Nil } \\
3.6 \\
4.7 \\
3.1 \\
6.1 \\
4.6\end{array}$ & $\begin{array}{c}4.2 \\
7.4 \\
\text { part } \\
\text { Nil } \\
6.6 \\
\text { part } \\
1 \cdot 7 \\
3 \cdot 9 \\
6 \cdot 0 \\
\text { part } \\
\text { part } \\
2 \cdot 5 \\
\text { Nil } \\
3.4 \\
1 \cdot 8 \\
4 \cdot 2 \\
5.5\end{array}$ & $\begin{array}{c}3 \cdot 5 \\
\text { part } \\
\text { Nil } \\
\text { Nil } \\
\text { part } \\
4 \cdot 1 \\
1 \cdot 1 \\
4 \cdot 0 \\
3 \cdot 6 \\
3 \cdot 0 \\
5 \cdot 8 \\
\text { N.C. } \\
\text { part } \\
\text { part } \\
\text { Nil } \\
5 \cdot 3 \\
\text { N.C. }\end{array}$ & $\begin{array}{l}\text { N.C. } \\
\text { N.C. } \\
\text { N.C. } \\
\text { N.C. } \\
\text { N.C. } \\
\text { N.C. } \\
0.6 \\
\text { N.C. } \\
\text { N.C. } \\
\text { N.C. } \\
\text { N.C. } \\
\text { N.C. } \\
\text { N.C. } \\
\text { N.C. } \\
\text { N.C. } \\
\text { N.C. } \\
\text { N.C. }\end{array}$ \\
\hline dean & $111 \cdot 58$ & & & & & 19 & 43 & & & & $4 \cdot 23$ & $8 \mathrm{ml}$. & \\
\hline
\end{tabular}

- N.C. $=$ not catheterized.

received no fluid other than that which they could obtain at the breast. Because of this the minute volumes obtained are less than those recorded by McCance and Young. They recorded minute volumes of the order of 0.1 to $0.15 \mathrm{ml}$. per minute which compares with a mean of $0.0682 \mathrm{ml}$. for this group of observations. The blood urea concentrations recorded by McCance and Young were lower, the average being $16.4 \mathrm{mg}$. urea per $100 \mathrm{ml}$. (7.66 mg. urea nitrogen per $100 \mathrm{ml}$.) compared with a mean of $19 \mathrm{mg}$. urea nitrogen per $100 \mathrm{ml}$. in this series. This difference in the two age periods is in conformity with the findings of Sedgwick and Ziegler (1920).

Despite these differences comparison may be made if the data are 'corrected' to an agreed standard. If the agreed standard be an adult standard, comparison may be made with it at the same time. The ratio between the body surface area, body weight, kidney weight, and the metabolic rate of the infant, and the corresponding data for an ideal theoretical adult have been suggested as correcting factors which might be used. McCance and Young (1941) have investigated the application of these various factors and on the data before them show that the body surface area factor is the most reasonable one to use.

After correcting each observation in group I to a standard of $1.73 \mathrm{sq}$. $\mathrm{m}$. body surface the observations were plotted after the manner of fig. 1 and averages were struck. These averages in the form of a graph are given in fig. 5. In the same figure there is given for comparison the graph for a theoretical adult having a surface area of $1.73 \mathrm{sq} . \mathrm{m}$. and a body weight of $70 \mathrm{~kg}$. The graph presented by McCance and Young (1941) representing the similarly corrected observations of their series is also given.

Comparison of these three graphs shows that judged by this standard the power of the kidney to clear urea from the blood in the immediate post natal period is far below that of the adult kidney and is also less than that of the two-week-old infant. In addition, the form of the graph representing the present observations differs from that representing the infant in the second week of life. The change in the form of the graph representing the observations of group 1 is sufficiently marked and abrupt to require some explanation.

Consideration of fig. 1 shows that the change in the form of the graph occurs at about a urine minute volume of $0.05 \mathrm{ml}$., that is, less than the mean minute volume. Also the impression is obtained that the scatter of the individual observations above $0.05 \mathrm{ml}$. per minute is much wider than the scatter at lower minute volumes. This impression is confirmed by the coefficient of correlation between the blood urea clearance and the urine minute volume which for the observations below $0.05 \mathrm{ml}$. urine per minute is +0.657 while for those above $0.05 \mathrm{ml}$. urine per minute it is +0.130 .

In a search for an explanation the following points may be considered. (1) The graph may represent all the kidney is required to do by way of 


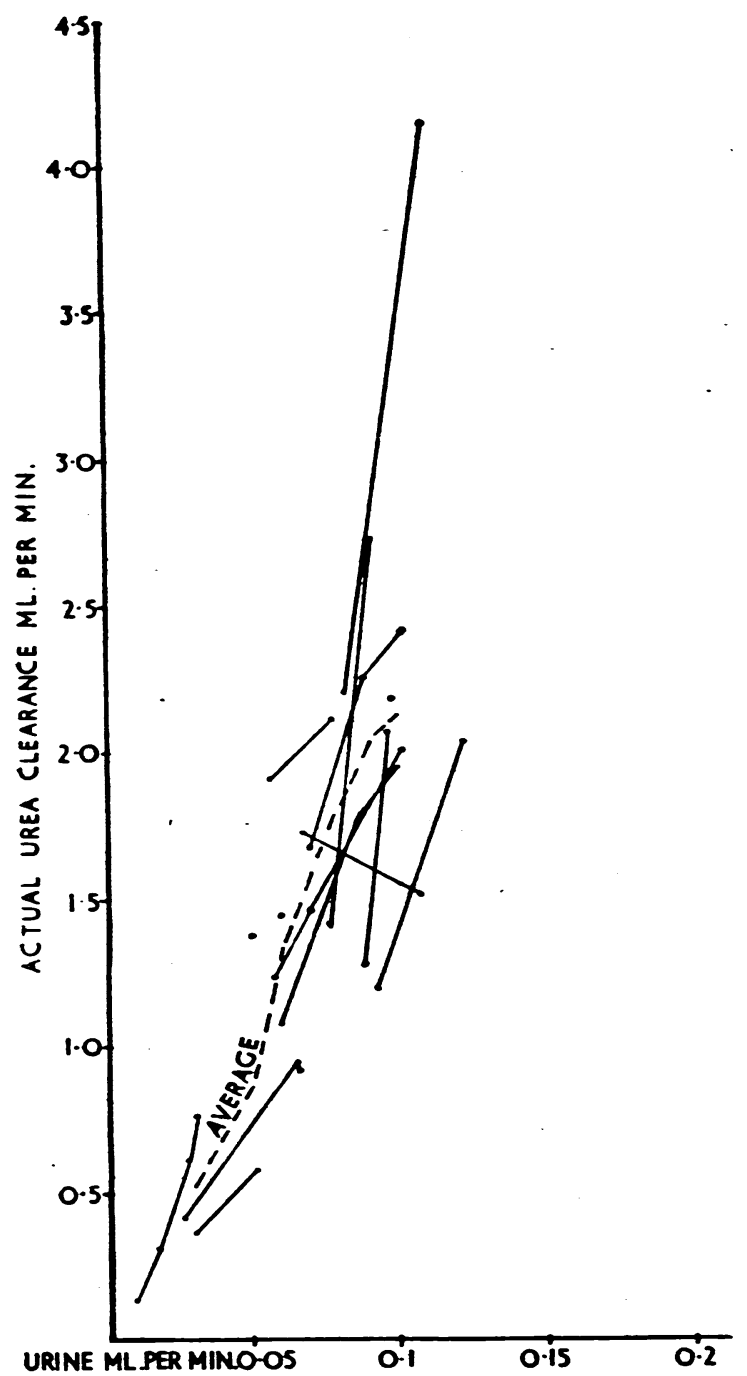

Fig. 3.-Group III: individual urea clearances.

urea clearance in the immediate post-natal period, and this may not be the same as the maximum clearing power; (2) in those observations showing urine minute volumes over $0.05 \mathrm{ml}$. per minute, the rate of flow through the tubules may have been too fast to permit of adequate concentration; (3) the possible effect upon the data of the failure of the infant to empty the bladder when voiding urine spontaneously.

The data obtained from group II gives some information on the first two of these points. The graph representing the averages of these observations shows little change in its form and is more like a straight line, fig. 2 . The urea fed to this group of infants has not produced a diuresis and

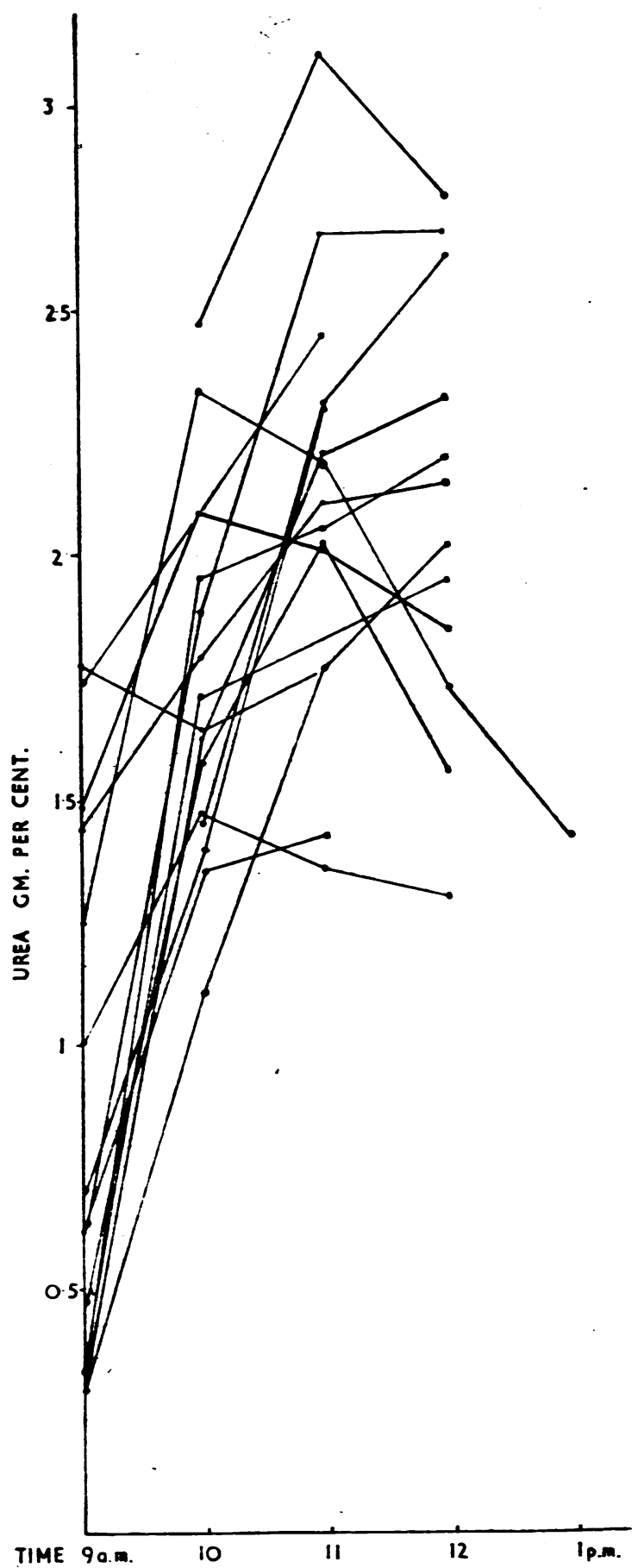

Fig. 4.-Group III: concentration of urea in urine. 
the difference between the urine minute volumes of groups I and II is not statistically significant. The group II observations corrected for surface area

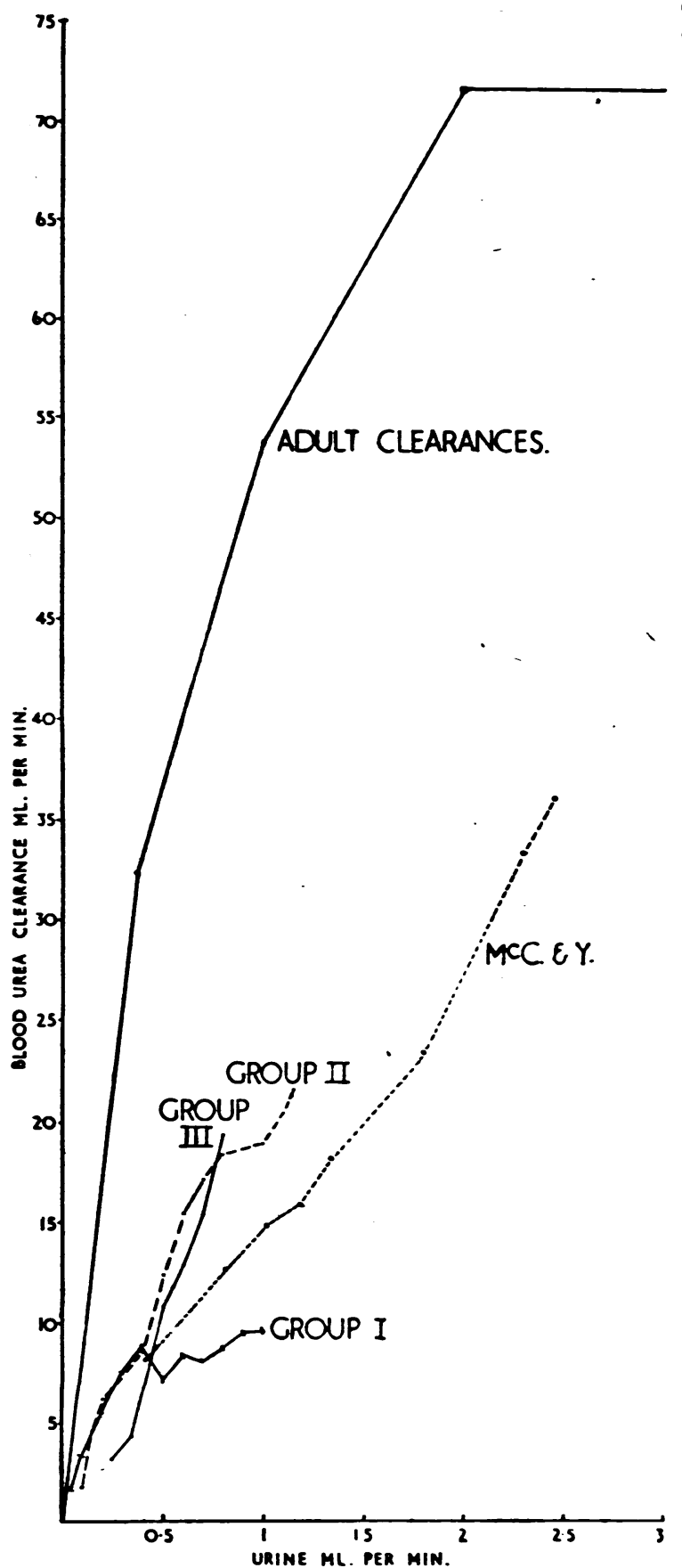

Fig. 5.-Comparison of infant and adult clearances on a basis of body surface area of $1.73 \mathrm{sq}$. $\mathrm{m}$. have been averaged in the same manner as the observations of group I, and are given as a graph in fig. 5. At urine minute volumes up to $0.4 \mathrm{ml}$. corrected the graphs for groups I and II virtually coincide. Above this point they diverge. It seems reasonable to infer from this that the urea clearances in groups I and II up to a urine minute volume of $0.05 \mathrm{ml}$. per minute are of the nature of maximum urea clearances and at urine minute volumes over this figure the maximum urea clearance rate is maintained by group II and not by group I. The group II observations also show that at urine minute volumes over $0.05 \mathrm{ml}$. the flow through the tubules is not too fast to permit of tubular resorption.

It will be observed that in calculating the clearances for group II it has been assumed that the blood urea nitrogen level remains constant throughout the observation period. Since it may well be doubted whether this is so, the blood urea nitrogen level was investigated several times in two infants. Fig. 6 shows the results obtained over a period of some forty-eight hours. In the same figure the blood urea nitrogen concentrations for all the infants in group II are given. In the case of the six infants who were not given urea at the commencement of the second observation period the blood urea nitrogen concentrations for the first and second periods have been joined by straight lines. The trend of these lines shows a certain resemblance to the graphs obtained from the two infants, $A$ and $B$, whose blood urea nitrogen concentrations were observed more frequently. There is little doubt that the blood urea nitrogen concentration remains at a high level initially and that it does so for periods comparable with the mean average duration of the observation period. Unfortunately the high concentrations are not necessarily stable, so that the data obtained in respect of group II are not free from objection. Moreover, the possible effect upon the data of the failure of an infant to empty the bladder is not considered in this group.

In group III, by shortening the period of observation to an average of two hours per infant and emptying the bladder by catheter at hourly intervals, one removes as far as possible the objection that the bladder may not be emptied at the time of voiding urine. One also mitigates in very large measure the objection that the blood urea nitrogen may not remain at a stable level during the observation period. This is shown by a comparison of the four blood urea nitrogen levels at 11 a.m. with those taken at 10 a.m. from the same infant (table 3).

On five occasions no urine was obtained on catheterizing, and no evidence could be found to show that the infant had voided urine spontaneously before being catheterized. Because of this it may be questioned whether the kidney secretes urine continuously. Be that as it may, the fact that there is no statistical significance in the differences between the urine minute volumes of the three groups suggests that from this point of view, at 
least, the observations of the three groups are comparable.

In group III as in group II urea did not produce a diuresis. The graph representing the averages of the observations in group III resembles the graph for group II in as much as it is almost a straight line (fig. 3).

The observations obtained from group III after individual correction for surface area, have been averaged in the same manner as the observations for groups I and II. This is shown in fig. 5. It is apparent from this representation that there is a great similarity between the averages of the observations for groups II and III so that the inference already drawn from a comparison of the graph representing groups I and II appears to be confirmed. The inference was that normally in the immediate post-natal period at urine minute volumes of $0.05 \mathrm{ml}$. or less (corrected $0.4 \mathrm{ml}$.) the urea clearance may be considered to be a maximum one; but that at urine minute volumes over this figure it is less than maximum.

In fig. 5 a comparison may also be made between the averages for groups II and III and the averages of the observations of McCance and Young. It is shown that the urea clearance in relation to the urine minute volume for groups II and III is greater than that which normally obtained in the second week of life. This observation suggests that the data of McCance and Young do not reflect the maximum clearing power of the kidney but rather a normal urea clearance for the age period. In the same figure (no. 5) comparison of groups II and III may also be made with the urea clearance of a standard adult of 1.73 sq. $\mathrm{m}$. body surface area. On this basis the urea clearances for groups II and III, though better than group I, shows that the kidney in the immediate post-natal period is less efficient than the adult kidney.

In their work on urea clearance McCance and Young showed that a basis of body weight was the only basis to which their observations could be corrected in order to reach a urea clearance comparable with that of an adult. They rejected this basis because of the very high urine minute volume which it entailed (fig. 7.) In view of the greater renal efficiency shown by groups II and III it was thought desirable to make a comparison between their urea clearances and those of a standard adult on a weight basis. After individual correction of the observations in each of groups II and III, averages were struck and graphs obtained. These graphs are shown in fig. 7. It is apparent that on this basis also an adult level of urea clearance has not been reached at any urine minute volume.

\section{Semmary}

1. The urea clearing power of the kidney in the immediate post-natal period has been investigated in three groups of infants.

2. Group I was a normal group comprising nine male infants. Group II consisted of thirteen male infants, and group III consisted of sixteen female

infants. At the commencement of the observation period $3 \mathrm{~g}$. of urea in $30 \mathrm{ml}$. of water were given by gavage to groups II and III.

3. Urine specimens from groups I and II were obtained by the use of a signalling apparatus. Urine specimens from group III were obtained by catheterization.

4. The urea clearances in group I are considered to be normal clearances, those from groups II and III to be maximum clearances.

5. Comparison of urea clearance between groups I, II, and III suggests that normally at urine minute volumes of $0.05 \mathrm{ml}$. or less, urea clearance is maximum, but at greater urine minute volumes the urea clearance is normally less than maximum.

6. Comparison of urea clearance between groups I, II, and III and urea clearance in infants over a week old shows that normally less urea is cleared in the immediate post-natal period.

7. Comparison of maximum urea clearance in the immediate post-natal period with the urea clearance of a standard adult having a surface area of $1.73 \mathrm{sq} . \mathrm{m}$. and a weight of $70 \mathrm{~kg}$. shows that on either basis of comparison urea clearance in the immediate post-natal period is less efficient. 


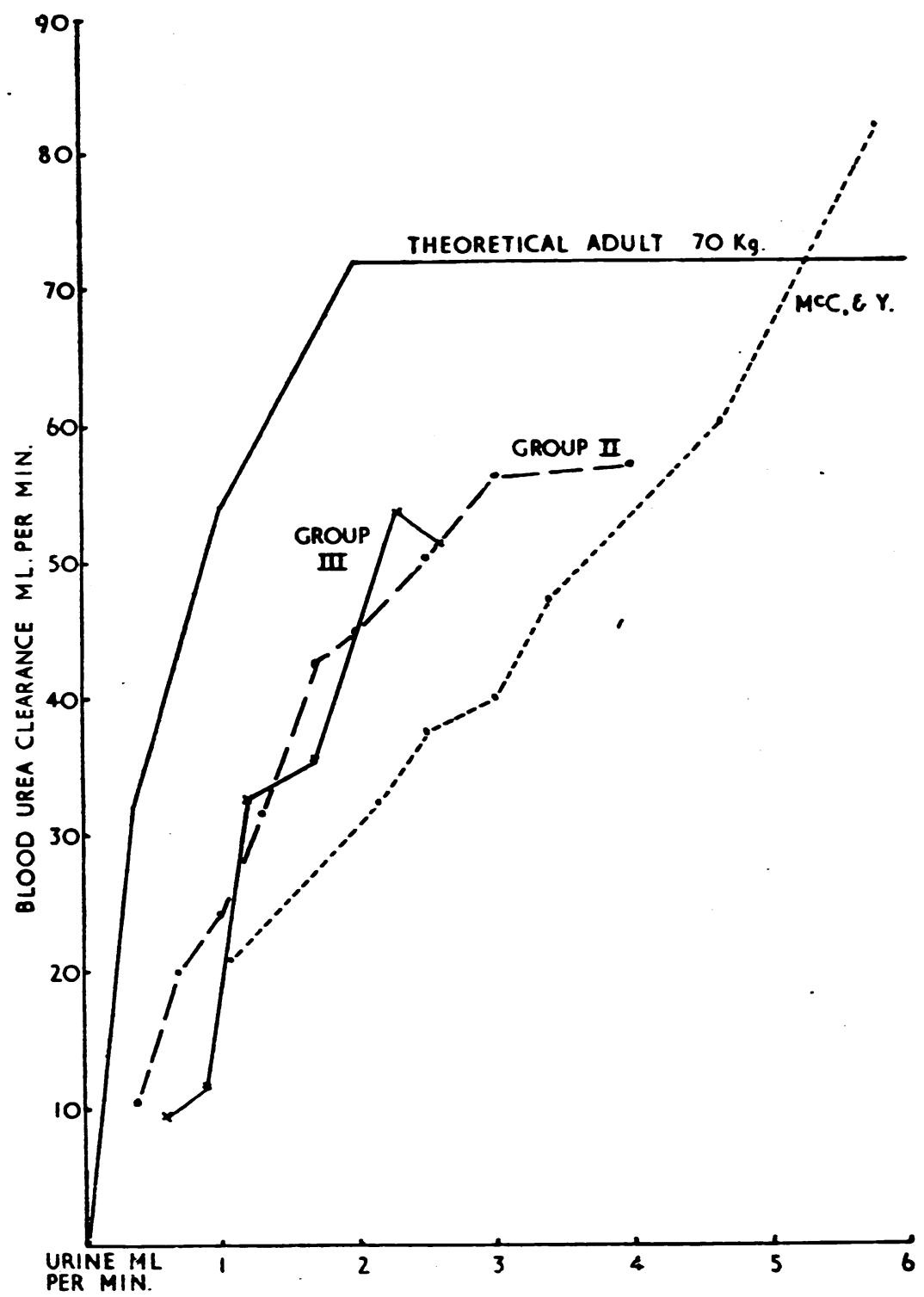

Fic. 7. - Comparison of infant and adult clearances on a basis of body weight of $70 \mathrm{~kg}$.

It is a great pleasure to acknowledge the technical services so willingly afforded me by Dr. C. P. Stewart, biochemist, Royal Infirmary, Edinburgh, and consulting biochemist, Royal Hospital for Sick Children, Edinburgh.

\section{Rererences}

Barnett, H. L. (1940). Proc. Soc. exp. Biol. N.Y., 44, 654.

-, Perley, A. M., and MoGinnis, H. G. (1942). Proc. Soc. exp. Biol. N.Y., 4, 90.

Dean, R. F. A., and McCance, R. A. (1947). J. Physiol., 1C6, 431 .
Gordon, H. H., Harrison, H. E., and McNamara, H. (1942). J. Clin. Invest., 21, 499.

Howland, J., and Dans R. T. (1913). Amer. J. Dis. Child., 6, 33.

Lucas, W. P., Dearing, B. F., Hoobler, H. R., Cox, A., Jones, M. R., and Smyth, F. S. (1921). Ibid., $22,525$.

MoCance, R. A., and Young, W.F.(1941). J.Physiol.,99, 265.

Schultz F. W., and Pettibone, C. J. V. (1915). Amer. J. Dis. Child., 10, 206.

Sedgwick, J. P., and Ziegler, M. R. (1920). Ibid., 19, 429.

Thomson, J. (1944). Arch. Dis. Child., 19, 169. 